\title{
Histone Deacetylase 7
}

National Cancer Institute

\section{Source}

National Cancer Institute. Histone Deacetylase 7. NCI Thesaurus. Code C102491.

Histone deacetylase 7 (952 aa, $103 \mathrm{kDa}$ ) is encoded by the human HDAC7 gene. This protein is involved in chromatin remodeling. 